\title{
Purification and Properties of D-Xylose Isomerase from Alkalophilic Bacillus No. KX-6
}

\author{
Ho-Joeng Kwon, Makio Kitada and Koki HoriKoshi \\ The Riken Institute, Wako-shi, Saitama 351-01, Japan
}

Received March 6, 1987

\begin{abstract}
An alkalophilic Bacillus No. KX-6 isolated from soil produced a D-xylose isomerase in alkaline media. The striking characteristic of this bacterium was its especially good growth in alkaline media. The D-xylose isomerase of this bacterium was purified by ammonium sulfate fractionation, DEAE-Sepharose ion exchange column chromatography and G-200 gel filteration. The molecular weight and sedimentation constant were approximately 120,000 and $9.35 \mathrm{~S}$, respectively. The enzyme was most active at $\mathrm{pH} 7 \sim 10$ and was stable at $\mathrm{pH} 6.0$ to 11.0 . Enzyme activity was stimulated by cobalt ion but inhibited by $\mathrm{Hg}^{2+}, \mathrm{Ag}^{2+}$, and $\mathrm{Cu}^{2+}$. Substrate specificity studies showed that this enzyme was active on D-xylose, D-glucose, D-ribose, and D-arabinose. The smaller $\mathrm{Km}$ value and larger $V_{\max }$ value for D-xylose indicated that this enzyme is essentially D-xylose isomerase.
\end{abstract}

$\mathrm{D}$-Xylose isomerase [D-xylose ketol isomerase, EC 5.3.1.5] occurs in various microorganisms, as have been reviewed by Bern $\mathbf{J}$. Schnyder et al. ${ }^{1)}$ Generally this enzyme is very heat-stable, active in the range $45 \sim 65^{\circ} \mathrm{C}$, and the reaction does not require any regenerating cofactor such as $\mathrm{NAD}^{+}$or ATP. Therefore it is important commercially for the isomerization of glucose to fructose.

Horikoshi reported that alkalophilic microorganisms produced alkaline enzymes. $^{2 \sim 5 \text { ) }}$ However, there have been no reports concerning D-xylose isomerases from alkalophilic microorganisms. In this study, we attempted to isolate some alkalophilic microorganisms that produced D-xylose isomerases, and as a result of screening we obtained one strain of bacteria, No. KX-6, which produces an isomerase active in a broad $\mathrm{pH}$ range. This paper deals with the isolation and characterization of this bacterium, and some properties of its D-xylose isomerase.

\section{MATERIALS AND METHODS}

Culture conditions. A D-xylose medium (AX-medium) was used for the isolation of $\mathrm{D}$-xylose isomerase pro- ducing bacteria: D-xylose, $5 \mathrm{~g}$; polypeptone, $5 \mathrm{~g}$; Difco yeast extract, $5 \mathrm{~g} ; \mathrm{K}_{2} \mathrm{HPO}_{4}, 1 \mathrm{~g} ; \mathrm{MnCl}_{2} \cdot 4 \mathrm{H}_{2} \mathrm{O}, 0.1 \mathrm{~g}$; $\mathrm{CoSO}_{4} \cdot 7 \mathrm{H}_{2} \mathrm{O}, 0.05 \mathrm{~g} ; \mathrm{Na}_{2} \mathrm{CO}_{3}, 10 \mathrm{~g}$; and 11 of water. Sodium carbonate was sterilized separately and added to the medium.

Isolation and selection of D-xylose isomerase producing alkalophilic bacteria. A small amount of soil was suspended in sterilized water and spread on agar plates of $\mathrm{AX}$ medium. After incubation for $2 \sim 3$ days at $37^{\circ} \mathrm{C}$, colonies which produced $\mathrm{D}$-xylose isomerase were inoculated into AX-medium and incubated at $37^{\circ} \mathrm{C}$ overnight with shaking. The D-xylose isomerase activity of the culture fluid was measured at $\mathrm{pH}$ 7.5. The alkalophilic Bacillus No. KX-6 was selected from about 150 colonies.

Characterization and identification of bacteria. Microbiological properties were investigated by the methods described in "Aerobic Sporeforming Bacteria"6) and "Bergey's Manual of Determinative Bacteriology."7) Unless otherwise stated, media used for the identification were supplemented with $1 \% \mathrm{Na}_{2} \mathrm{CO}_{3}$.

Preparation of crude enzyme solution. Bacillus No. KX-6 was grown with shaking on a rotary shaker at $37^{\circ} \mathrm{C}$ overnight in AX-medium. Cells were harvested at $4{ }^{\circ} \mathrm{C}$ for $10 \mathrm{~min}$ at $8,000 \times g$, and washed twice with $0.05 \mathrm{M}$ phosphate buffer ( $\mathrm{pH} 7.5$ ). The washed cells were suspended in a $0.05 \mathrm{~m}$ phosphate buffer $(\mathrm{pH} .7 .5)$ and then sonicated $(20 \mathrm{kHz}, 200 \mathrm{Watts})$ for $3 \mathrm{~min}$ in an ice bath. Cell debris was removed by centrifugation at $8,000 \times g$ for $10 \mathrm{~min}$ at $4^{\circ} \mathrm{C}$. The supernatant fluid was used as a crude prepara- 
tion of D-xylose isomerase.

Enzyme assays. D-Xylose isomerase was assayed with the standard assay mixture described previously. ${ }^{8,9)}$ The $\mathrm{pH}$ of the mixture was 7.5 in $0.05 \mathrm{~m}$ phosphate buffer. The xylulose formed was measured by the cysteine-carbazole method. ${ }^{10)}$ One unit of enzyme is defined as the amount of enzyme producing $1.0 \mu \mathrm{mol}$ of xylulose per min in the standard reaction mixture. Specific activity was expressed as units of the enzyme per mg of protein.

Protein measurement. Protein was measured by the Lowry method ${ }^{11)}$ with bovine serum albumin as the standard.

Polyacrylamide gel electrophoresis. To examine the homogeneity of the purified enzyme preparation, PAGE was done on $10 \%(\mathrm{w} / \mathrm{v})$ polyacrylamide gels with a Tris- $\mathrm{HCl}$ buffer system ( $\mathrm{pH} 8.3$ ). About $5 \mu \mathrm{g}$ purified enzyme was put on each gel and run at a constant current of $2 \mathrm{~mA}$ per tube until the tracing dye, BPB, reached the bottom of the tiube. The protein was stained with $2.5 \%$ Coomassie blue. The D-xylose isomerase was actively stained by the method of Yamanaka et al. $^{9 \text { ) }}$

Molecular weight measured. The molecular weight of the enzyme was estimated by the SDS-PAGE method of Laemmli, ${ }^{12)}$ gel filtration chromatography, and ultracentrifugal analysis. Molecular weight markers were obtained from BIO-RAD and a Hitachi Analytical Ultracentrifuge UCA-1 was used for ultracentrifugal analysis. The sedimentation constant was calculated by the method of Schachman. ${ }^{13)}$

Isoelectric focusing. Isoelectric focusing was done on Servalyt Procotes, $\mathrm{pH}$ range 3-6 (Serva). Sample $(5 \mu \mathrm{l})$ containing $5 \mu \mathrm{g}$ of protein were put on the sample applicator. The gel was prefocused at $5.5 \mathrm{~W}$ for $90 \mathrm{~min}$ and the proteins were stained with Coomassie blue.

Amino acid analysis. A Hitachi 835 amino acid analyzer was used. The samples were hydrolyzed in $6 \mathrm{~N} . \mathrm{HCl}$ at $110^{\circ} \mathrm{C}$ for $24 \mathrm{hr}$. The tryptophan content was estimated by $4 \mathrm{~N}$ methanesulfonic acid hydrolysis at $110^{\circ} \mathrm{C}$ for $24 \mathrm{hr}$.

Reagents. D-Xylose was obtained from the Tokyo Kasei Chemical Co. All other chemicals used were of the highest quality available commercially.

\section{RESULTS}

\section{Characteristics of the isolate}

The isolated strain No. KX-6 was an aerobic, sporeforming, gram positive, motile, and rod-shaped bacterium, clearly in the genus Bacillus. The striking characteristic of the
Table I. Morphological, Cultural, AND Biochemical Characteristics of Strain KX-6

\begin{tabular}{|c|c|c|}
\hline \multirow{2}{*}{\multicolumn{3}{|c|}{ Morphological characteristics }} \\
\hline & & \\
\hline \\
\hline \multicolumn{3}{|c|}{ Motility, Motile; Gram stain, Positive; } \\
\hline \multicolumn{3}{|c|}{ Spores, Ellipsoidal, Central; } \\
\hline \multicolumn{3}{|l|}{ Cultural characteristics } \\
\hline & \multicolumn{2}{|c|}{ Growth at } \\
\hline & $\mathrm{pH} 7$ & $\mathrm{pH} 10$ \\
\hline Nutrient broth & - & + \\
\hline Nutrient agar slant & - & + \\
\hline Glucose nutrient broth & - & + \\
\hline Glucose nutrient agar slant & - & + \\
\hline Peptone water & - & + \\
\hline \multicolumn{3}{|l|}{ Biochemical characteristics } \\
\hline Hydrolysis of starch & \multicolumn{2}{|c|}{ Positive } \\
\hline Hydrolysis of gelatine and casein & \multicolumn{2}{|c|}{ Positive } \\
\hline Use of citrate & \multicolumn{2}{|c|}{ Positive } \\
\hline Ruduction of nitrate to nitrite & \multicolumn{2}{|c|}{ Reduced } \\
\hline Voges-Proskauer test & \multicolumn{2}{|c|}{ Negative } \\
\hline Catalase & \multicolumn{2}{|c|}{ Positive } \\
\hline Growth in $\mathrm{NaCl}$ & \multicolumn{2}{|c|}{$7 \%$} \\
\hline $\mathrm{G} / \mathrm{C}$ content & \multicolumn{2}{|c|}{$43.9 \%$} \\
\hline $\mathrm{pH}$ for growth & \multicolumn{2}{|c|}{$\mathrm{pH} 7.5 \sim 11$} \\
\hline Temperature for growth & \multicolumn{2}{|c|}{ Up to $42^{\circ} \mathrm{C}$} \\
\hline
\end{tabular}

microorganism was that its growth was very good in alkaline media, and the optimal $\mathrm{pH}$ for growth was about 10. Table I summarizes the morphological and cultural characteristics of strain KX-6. It was similar to Bacillus circulans in taxonomic characteristics, except for growth $\mathrm{pH}$.

\section{Culture conditions for production of the enzyme}

The production of D-xylose isomerase was examined in media containing sodium carbonate or various carbonate salts. The effects of the addition of sodium chloride or potassium chloride were also tested. D-Xylose isomerase activity after overnight cultivation was measured. The results are shown in Table II, which indicate the addition of carbonate or bicarbonate salts is important for the production of $\mathrm{D}$-xylose isomerase.

\section{Purification of the enzyme}

Unless otherwise stated, all purification was done at $4^{\circ} \mathrm{C}$. The washed Bacillus No. KX-6 cells (104 $\mathrm{g}$ wet weight from $7 \mathrm{l}$ ) were suspended in $0.05 \mathrm{~m}$ phosphate buffer ( $\mathrm{pH} 7.5$ ). Each 
$50-\mathrm{ml}$ portion of cell suspension was treated by a French press at $1,100 \mathrm{~kg} / \mathrm{cm}^{2}$. Cell-free extracts were obtained by centrifugation at $8,000 \times g$ for $10 \mathrm{~min}$. Unbroken cells were resuspended in the same buffer and the French press treatment repeated in the same manner. The first and second supernatants were combined and centrifuged at $25,000 \times g$ for $30 \mathrm{~min}$. This supernatant $(4 \mathrm{u} / \mathrm{ml})$ was fractionated with ammonium sulfate and the precipitate formed between $45 \% \sim 90 \%$ saturation was collected, dissolved in $0.05 \mathrm{~m}$ phosphate buffer, $\mathrm{pH} 7.5$, and then dialyzed overnight against the buffer used for the dissolution. The dialyzed solution was put on a DEAE-Sepharose CL-6B column $(1.5 \times 40 \mathrm{~cm})$ that was equilibrated with $0.05 \mathrm{M}$ Tris- $\mathrm{HCl}, \mathrm{pH} 7.5$. The column was then washed with $300 \mathrm{ml}$ each of the same buffer containing $0.0 \mathrm{M}, 0.1 \mathrm{M}$ and $0.2 \mathrm{M}$ $\mathrm{NaCl}$. These washes removed a substantial amount of protein and no enzyme activity was found in the eluates. A fraction containing the

Table II. D-Xylose Isomerase Production IN VARIOUS MEDIA

\begin{tabular}{|c|c|c|c|}
\hline \multicolumn{2}{|c|}{$\begin{array}{l}\text { Salts added to } \\
\text { a basal medium }\end{array}$} & Initial $\mathrm{pH}$ & $\begin{array}{l}\mathrm{D} \text {-Xylose } \\
\text { isomerase } \\
\text { (units } / \mathrm{ml} \text { ) }\end{array}$ \\
\hline \multicolumn{2}{|l|}{ None } & 7.2 & $\mathrm{ND}^{b}$ \\
\hline $\mathrm{NaCl}^{a}$ & $1.0 \%$ & 10.5 & ND \\
\hline $\mathrm{KCl}^{a}$ & $1.0 \%$ & 10.5 & ND \\
\hline $\mathrm{NaCO}_{3}$ & $0.5 \%$ & 9.6 & 1.0 \\
\hline $\mathrm{NaCO}_{3}$ & $1.0 \%$ & 10.1 & 1.3 \\
\hline $\mathrm{NaCO}_{3}$ & $1.5 \%$ & 10.5 & 0.5 \\
\hline $\mathrm{NaHCO}$ & $1.0 \%$ & 8.9 & 0.7 \\
\hline $\mathrm{NaHCO}$ & $2.0 \%$ & 9.3 & 1.2 \\
\hline
\end{tabular}

a The $\mathrm{pH}$ was adjusted with $\mathrm{NaOH}$. Basal medium is the AX-medium minus $\mathrm{NaCO}_{3}$.

$b$ ND, undetectable. enzyme was eluted with $200 \mathrm{ml}$ of buffer containing $0.3 \mathrm{M} \mathrm{NaCl}$. This fraction was dialyzed

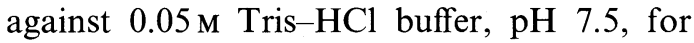
$3 \mathrm{hr}$ and then put on another DEAESepharose CL-6B column $(1.6 \times 30 \mathrm{~cm})$ that had been equilibrated with the same buffer. After the column was washed with $200 \mathrm{ml}$ of equilibration buffer containing $0.1 \mathrm{M} \mathrm{NaCl}$, a linear gradient $(300 \mathrm{ml}$ total) from $0.1 \mathrm{M}$ to $0.4 \mathrm{M} \mathrm{NaCl}$ in the equilibration buffer was used to elute the D-xylose isomerase. The enzyme protein was eluted with 0.25 to $0.3 \mathrm{M} \mathrm{NaCl}$ at $\mathrm{pH} 7.5$ and the active fractions (No. 27 33, $5 \mathrm{ml}$ each) were pooled. In the final step, the collected fractions containing D-xylose isomerase were put on a S-200 column $(2.2 \times 90 \mathrm{~cm})$ equilibrated with $0.05 \mathrm{M}$ Tris- $\mathrm{HCl}$ buffer, $\mathrm{pH}$ 7.5 , containing $0.1 \mathrm{M} \mathrm{NaCl}$. The D-xylose isomerase thus obtained was purified about 10 -fold, and designated as the purified enzyme in this paper. The results are summarized in Table III.

\section{Physical and chemical properties}

PAGE and activity staining of the purified D-xylose isomerase (Fig. 1) showed that the enzyme was homogeneous, and ultracentrifugal analysis showed only one peak throughout the duration of a run of $120 \mathrm{~min}$ at $60,000 \mathrm{rpm}$. The sedimentation constant of the enzyme at $\mathrm{pH} 8.0(0.05 \mathrm{M}$ Tris- $\mathrm{HCl}$ containing $0.1 \mathrm{M} \mathrm{NaCl}$ ) was about $9.35 \mathrm{~S}$. The molecular weight of the enzyme estimated by gel filtration through a Toyopearl HW 55 column $(2.2 \times 90 \mathrm{~cm})$ was about 120,000 by comparison with standard proteins (Fig. 2). Electrophoresis of the SDS-treated enzyme preparations on SDS-PAGE $(10 \%)$ revealed

Table III. Purification of Xylose Isomerase of Bacillus KX-6.

\begin{tabular}{lccccc}
\hline Steps & $\begin{array}{c}\text { Volume } \\
(\mathrm{ml})\end{array}$ & $\begin{array}{c}\text { Activity } \\
\text { (units) }\end{array}$ & $\begin{array}{c}\text { Protein } \\
(\mathrm{mg})\end{array}$ & $\begin{array}{c}\text { Specific activity } \\
\text { (units/mg protein) }\end{array}$ & Purification \\
\hline Crude extract & 210 & 850 & 1176 & 0.72 & 1 \\
$\left(\mathrm{NH}_{4}\right)_{2} \mathrm{SO}_{4}$ ppt $45 \sim 90 \%$ & 50 & 785 & 595 & 1.32 & 1.8 \\
1st DEAE-Sepharose & 20 & 560 & 320 & 1.75 & 2.4 \\
2nd DEAE-Sepharose & 30 & 478 & 95 & 5.03 & 7.0 \\
Sephacryl S-200 & 15 & 194 & 26 & 7.50 & 10.4 \\
\hline
\end{tabular}


A

B

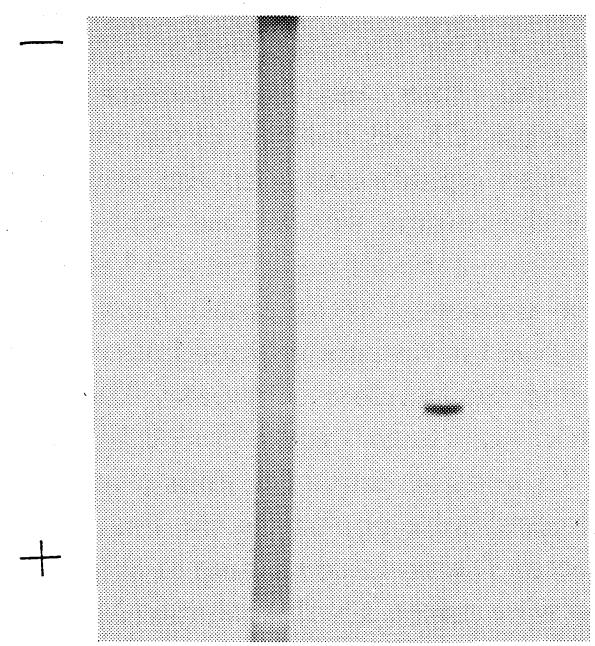

Fig. 1. Electrophoretic Profile of Xylose Isomerase in Polyacrylamide Gel.

(A), active staining by triphenyltetrazolum; (B), stained by Coomassie brilliant blue.

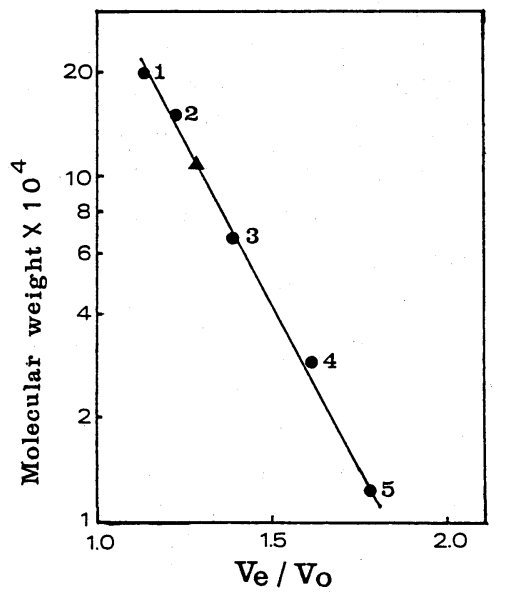

FIG. 2. Estimation of Molecular Weight of D-Xylose Isomerase by Gel Filtration Chromatography on Toyopearl HW 55.

Standard proteins: $1, \beta$-amylase $(200,000) ; 2$, alcohol dehydrogenase $(150,000) ; 3$, bovine serum albumin $(66,000) ; 4$, carbonic anhydrase $(29,000) ; 5$, cytochrome $(12,400)$. Sample: $\boldsymbol{\Delta}, \mathrm{KX}-6$ xylose isomerase.

one band with a molecular weight of 58,000 . Therefore, we concluded that the D-xylose isomerase of Bacillus KX-6 was has two identical subunits of 58,000 molecular weight. The isoelectric point of the enzyme measured using
TABle IV. Amino ACid Composition of D-XYLOSE ISOMERASE

\begin{tabular}{lrrr} 
& \multicolumn{3}{c}{ Number of residues/molecule } \\
\cline { 2 - 4 } Amino acids & No. & & \\
& KX-6 & Streptomyces $^{19)}$ & Bacillus $^{15}$ ) \\
& & & \\
\hline Aspartic acid & 121 & 180 & 182 \\
Threonine & 58 & 56 & 87 \\
Serine & 51 & 36 & 70 \\
Glutamic acid & 105 & 152 & 136 \\
Proline & 27 & 72 & 44 \\
Glycine & 95 & 140 & 106 \\
Alanine & 84 & 180 & 140 \\
Half-cysteine & 0 & 4 & 0 \\
Valine & 55 & 72 & 53 \\
Methionine & 25 & 32 & 27 \\
Isoleucine & 45 & 40 & 51 \\
Leucine & 86 & 144 & 135 \\
Tyrosine & 97 & 36 & 58 \\
Phenylalanine & 63 & 92 & 96 \\
Histidine & 34 & 40 & 49 \\
Lysine & 67 & 40 & 120 \\
Arginine & 34 & 132 & 61 \\
Tryptophan & 8 & 32 & 13 \\
\hline & & & \\
\hline
\end{tabular}

Servalyt Precote was pH 4.5 and no other peak of the activity was detected. The amino acid composition of D-xylose isomerase is shown in Table IV together with those of other bacterial $D$-xylose isomerases. The tyrosine content is higher than that of other D-xylose isomerases; no cysteine residues were detected.

\section{Effects of $\mathrm{pH}$ on activity and stability}

The $\mathrm{pH}$ optimum of $\mathrm{D}$-xylose isomerase was

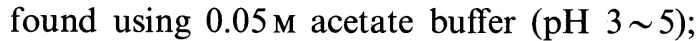
$0.05 \mathrm{~m}$ sodium phosphate buffer ( $\mathrm{pH} 6 \sim 8$ ); $0.05 \mathrm{M}$-glycine- $\mathrm{NaCl}-\mathrm{NaOH}$ buffer ( $\mathrm{pH} 8.5 \sim$ $10.5)$ and $0.05 \mathrm{M}-\mathrm{Na}_{2} \mathrm{CO}_{3}-\mathrm{NaOH}$ buffer $(\mathrm{pH}$ $11 \sim 12.5)$. The other conditions were the same as for the standard assay method. The Dxylose isomerase was most active at $\mathrm{pH} 7 \sim 9$, and still retained activity at $\mathrm{pH} 10$ (Fig. 3). Stability of the enzyme was investigated in buffer solutions of various $\mathrm{pHs}$. The mixture was incubated for $30 \mathrm{~min}$ at $40^{\circ} \mathrm{C}$ and residual activity was measured at $\mathrm{pH} 7.5$. The following buffer systems were used; $0.05 \mathrm{M}$ acetate buffer ( $\mathrm{pH} 3 \sim 5$ ); $0.05 \mathrm{M}$ sodium phosphate buffer (pH $6 \sim 8$ ); 0.05 M glycine--NaCl-NaOH buffer 


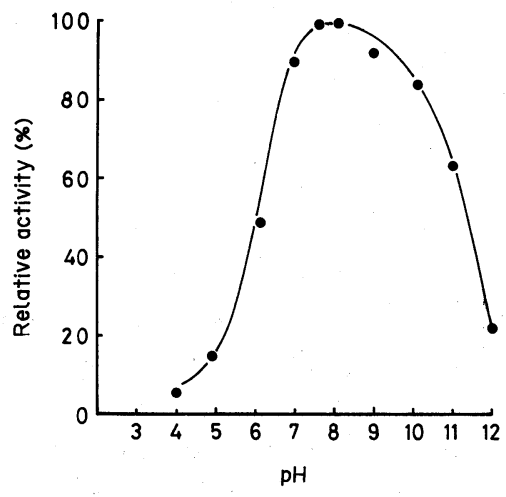

Fig. 3. Effects of $\mathrm{pH}$ on Enzyme Activity.

The following buffer systems were used: $0.05 \mathrm{M}$ acetate buffer ( $\mathrm{pH} 3 \sim 5$ ); $0.05 \mathrm{M}$ sodium phosphate buffer $(\mathrm{pH}$ $6 \sim 8) ; 0.05 \mathrm{M}$ glycine- $\mathrm{NaCl}-\mathrm{NaOH}$ buffer $(\mathrm{pH} 8.5 \sim 10.5)$, and $0.05 \mathrm{M} \mathrm{Na}_{2} \mathrm{CO}_{3}-\mathrm{NaOH}$ buffer ( $\mathrm{pH} 11 \sim 12.5$ ). Other conditions were the same as for the standard assay method.

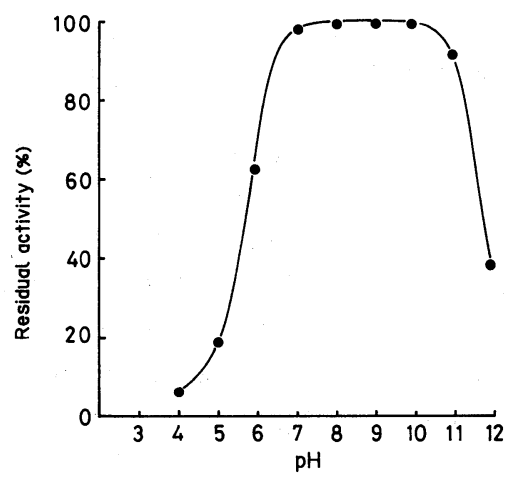

FIG. 4. Effect of $\mathrm{pH}$ on Stability.

Buffer systems used were acetate $(0.05 \mathrm{M}, \mathrm{pH} 3 \sim 5)$; sodium phosphate $(0.05 \mathrm{M}, \mathrm{pH} 6 \sim 8)$; glycine- $\mathrm{NaCl}-\mathrm{NaOH}$ $(0.05 \mathrm{M}, \mathrm{pH} 8.5 \sim 10.5)$, and $\mathrm{Na}_{2} \mathrm{CO}_{3}-\mathrm{NaOH}(0.05 \mathrm{M}, \mathrm{pH}$ $11 \sim 12.5$ ). The reaction mixtures were incubated at $40^{\circ} \mathrm{C}$ for $30 \mathrm{~min}$ and residual activity was measured at $\mathrm{pH}$ 7.5.

(pH $8.5 \sim 10.5$ ) and $0.05 \mathrm{M}-\mathrm{Na}_{2} \mathrm{CO}_{3}-\mathrm{NaOH}$ buffer (pH $11 \sim 12.5$ ). As shown in Fig. 4, the enzyme was stable at $\mathrm{pH} 6.0 \sim 11.0$.

\section{Temperature optimum for the enzyme action and thermal stability}

The optimum temperature was found under the usual assay conditions while the temperature was varied over a range of $40^{\circ} \mathrm{C}$ to $80^{\circ} \mathrm{C}$. Figure 5 shows that the optimum temperature of the enzyme is $60^{\circ} \mathrm{C}$. The thermostability of

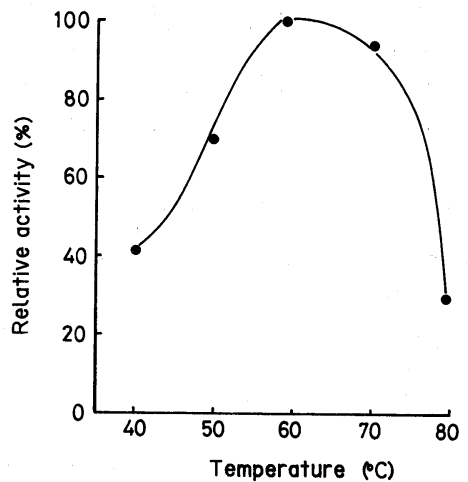

FIG. 5. Optimum Temperature.

The reaction was done at $\mathrm{pH} 7.5$ for $10 \mathrm{~min}$ at each temperature.

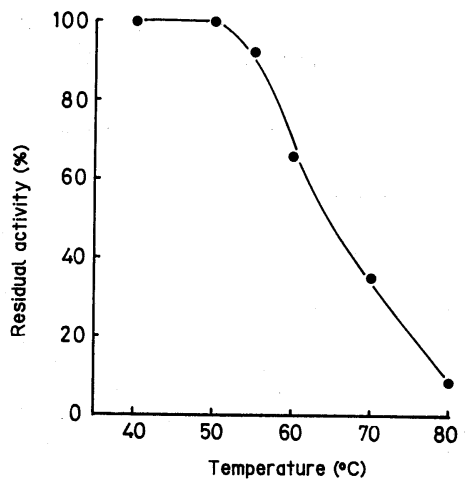

FIG. 6. Thermal Stability of Enzyme.

The reaction was done incubating the enzyme solution ( $1 \mathrm{unit} / \mathrm{ml}, 1 \mathrm{~mm} \mathrm{CoCl} \mathrm{CH}_{2} \mathrm{p.5}$ ) at each temperature for $30 \mathrm{~min}$, and residual activity was measured at $\mathrm{pH}$ 7.5.

the enzyme was examined by incubating enzyme solutions ( $1 \mathrm{unit} / \mathrm{ml}, 1 \mathrm{~mm} \mathrm{CoCl}{ }_{2} \mathrm{pH} 7.5$ ) at temperatures of $40^{\circ} \mathrm{C}$ to $80^{\circ} \mathrm{C}$ for $30 \mathrm{~min}$, and residual activity was measured at $\mathrm{pH}$ 7.5. As shown in Fig. 6, the residual activity was $100 \%$ when heated at $40 \sim 55^{\circ} \mathrm{C}$, and the enzyme gradually lost its activity above $60^{\circ} \mathrm{C}$.

\section{Substrate specificity}

$0.1 \mathrm{ml}$ of the enzyme solution ( 5 units $/ \mathrm{ml}$ ) and $0.1 \mathrm{ml}$ of one of $1 \%$ solutions of various sugars were mixed and incubated at $50^{\circ} \mathrm{C}$ overnight. The mixture was put on an Avicel SF plate and developed with a solvent system of butanol-pyridine-water $(6: 4: 3, \mathrm{v} / \mathrm{v})$. The sugars were $\cdot$ detected using naphthoresorcinol 
Table V. Substrate Specificity

\begin{tabular}{lc}
\hline Substrate & Degree of ketose formation \\
\hline D-Xylose & ++ \\
L-Xylose & - \\
D-Glucose & + \\
D-Mannose & - \\
D-Galactose & - \\
D-Ribose & + \\
D-Sorbose & - \\
D-Lactose & - \\
D-Arabinose & + \\
\hline
\end{tabular}

- , negative; + , positive; ++ , strongly positive.

Substrate specificity was measured by thin-layer chromatography using $1 \%$ sugar solution and enzyme solution mixture incubated at $50^{\circ} \mathrm{C}$ overnight.

Table VI. Effects of Some Metals and Inhibitors on Xylose Isomerase Activity

\begin{tabular}{lcc}
\hline Reagents & $\begin{array}{c}\text { Concentration } \\
(\mathrm{mM})\end{array}$ & $\begin{array}{c}\text { Relative activity } \\
(\%)\end{array}$ \\
\hline $\mathrm{None}$ & & 100 \\
$\mathrm{HgCl}_{2}$ & 1 & 8 \\
$\mathrm{CuSO}_{4}$ & 1 & 33 \\
$\mathrm{AgNO}_{3}$ & 1 & 27 \\
$\mathrm{PbCl}$ & 1 & 67 \\
$\mathrm{FeSO}_{4}$ & 1 & 72 \\
$\mathrm{ZnSO}_{4}$ & 1 & 61 \\
$\mathrm{MgSO}_{4}$ & 1 & 100 \\
$\mathrm{BaSO}_{4}$ & 1 & 97 \\
$\mathrm{MnCl}_{2}$ & 1 & 114 \\
$\mathrm{CoCl}_{2}$ & 1 & 131 \\
$\mathrm{CaCl}_{2}$ & 1 & 100 \\
$\mathrm{NiSO}_{4}$ & 1 & 92 \\
$\mathrm{PCMB}_{\mathrm{EDTA}}$ & 0.1 & 103 \\
& 10 & 98
\end{tabular}

reagent. As shown in Table $\mathrm{V}$, the enzyme was specially active on D-xylose, but showed some affinity for D-glucose. The Michaelis constant and $V_{\max }$ value for D-xylose were $0.076 \mathrm{M}$ and $50 \mu \mathrm{mol} / \mathrm{min} / \mathrm{mg}$, respectively.

\section{Effects of metals and inhibitors}

The enzyme solution $(0.02 \mathrm{ml})$ was mixed with $0.2 \mathrm{ml}$ of $0.05 \mathrm{M}$ phosphate buffer ( $\mathrm{pH} 7.5$ ) containing a test reagent and incubated at $37^{\circ} \mathrm{C}$ for $10 \mathrm{~min}$. Then $0.2 \mathrm{ml}$ of the substrate (50 mm xylose) was added. As shown in Table $\mathrm{VI}, \mathrm{Co}^{2+}$ and $\mathrm{Mn}^{2+}$ activated the enzyme reaction, but $\mathrm{Hg}^{2+}, \mathrm{Ag}^{2+}$, and $\mathrm{Cu}^{2+}$ inhibited the enzyme.

\section{DISCUSSION}

A strain of Bacillus No. KX-6, a newly isolated soil bacterium, produced a $\mathrm{D}$-xylose isomerase in a highly alkaline medium containing $\mathrm{Na}_{2} \mathrm{CO}_{3}$. The microbiological properties of the isolate were very similar to those of $B$. circulans. However, the isolate was distinguished from typical strains of $B$. circulans in the growth $\mathrm{pH}$; the isolate could grow and produce enzyme better in alkaline media rather than in neutral ones. It is noteworthy that D-xylose isomerase was only produced in alkaline media containing carbonate or bicarbonate salts. The homogeneity of the purified enzyme was supported by PAGE, ultracentrifugal analysis, gel filtration, and isoelectric focusing. The enzyme was most active at $\mathrm{pH}$ $7 \sim 9$ which is a much broader range than that of other D-xylose isomerases. ${ }^{14 \sim 18)}$ The Dxylose isomerases of Streptomyces ${ }^{18,19)}$ were activated by $\mathrm{Co}^{2+}$ and $\mathrm{Mg}^{2+}$. However, the enzyme of Bacillus No. KX-6 was activated strongly by $\mathrm{Co}^{2+}$ and $\mathrm{Mn}^{2+}$. No activation by $\mathrm{Mg}^{2+}$ and $\mathrm{Ca}^{2+}$ were observed. This enzyme was inhibited by $\mathrm{Ag}^{2+}, \mathrm{Hg}^{2+}$ and $\mathrm{Cu}^{2}$ like other D-xylose isomerases. ${ }^{14 \sim 19)}$ Inactivation by $\mathrm{Hg}^{2+}$ suggests the presence of a thiol group, although other thiol agents such as $p$ chloromercuribenzoate were ineffective. The physical properties of the enzyme were very similar to those of Bacillus coagulans ${ }^{15}$ and Bacillus stearothermophilus ${ }^{16)}$ except that Bacillus KX-6 enzyme dissociated into 2 subunits. Another distinctive feature of enzyme was its low molecular weight. The molecular weight of the enzyme estimated by the Archibald method was approximately 130,000 and the gel filteration method gave 120,000. This value is smaller than the enzymes produced by Streptomyces albus (165,000 with 4 subunits of 41,500$),{ }^{19)}$ Streptomyces $\mathrm{sp}$. $(157,000),{ }^{18)}$ Bacillus coagulans $(167,000$ with 4 subunits of 49,000$),{ }^{15}$ Lactobacillus xylosus $(183,000 \text { with } 4 \text { subunits of } 45,000)^{14)}$ and 
Bacillus stearothermophilus (130,000 with no subunits). ${ }^{16)}$ Some differences in amino acid composition were also found from other bacterial D-xylose isomerases. ${ }^{15,16,19)}$ The enzyme of Bacillus KX-6 had more tyrosine than those of Streptomyces sp. and Bacillus sp. These results seem to suggest some differences in their enzymatic properties. Further investigation is required. We conclude that the $\mathrm{D}$ xylose isomerase of $\mathrm{KX}-6$ is different from other D-xylose isomerases so far reported, especially in its broad $\mathrm{pH}$ stability and protein properties.

Acknowledgment. I wish to thank Mr. M. Chijimatsu of the Institute for his courtesy in the ultracentrifugal and amino acid analyses.

\section{REFERENCES}

1) M. D. Lilly, "Applied Biochemistry and Bioengineering," Academic press, New York, 1979, p. 103.

2) K. Horikoshi, Agric. Biol. Chem., 35, 1405 (197.1).

3) K. Horikoshi, Agric. Biol. Chem., 36, 285 (1972).

4) K. Horikoshi and Y. Atsukawa, Agric. Biol. Chem., 37, 2097 (1973).

5) K. Horikoshi and T. Akiba, "Alkalophilic
Microorganisms, a New Microbial World,' Springer-Verlag, New York, 1982.

6) N. R. Smith, R. E. Gordon and F. E. Clark, "Aerobic Sporeforming Bacteria," U. S. Dept. of Agri., 1952.

7) R. E. Buchanan and V. E. Gibbons, "Bergey's Manual of Determinate Bacteriology," 8th Ed., The Williams and Wilkins Co., Baltimore, 1974.

8) K. Yamanaka, Biochim. Boiphys. Acta, 151, 670 (1968).

9) K. Yamanaka, "Methods in Enzymology," Vol XLI, ed. by W. A. Wood, Academic Press Inc., New York, 1975, p. 466.

10) Z. Diche and E. Borenfreud, J. Biol. Chem., 192, 583 (1951)

11) D. H. Lowry, N. J. Rosebrough, A. L. Farr and R. J. Randall, J. Biol. Chem., 193, 265 (1951).

12) Laemmli, U. K., Nature (London), 227, 680 (1970).

13) H. K. Schachman, "Method in Enzymology," ed. by C. P. Colowick and N. O. Koplan, Academic Press Inc., New York, 1957, p. 32.

14) K. Yamanaka and N. Takahara, Agric. Biol. Chem., 41, 1909 (1977).

15) G. Danno, Agric. Biol. Chem., 34, 1795 (1970).

16) M. Suekane, M. Tamura and C. Tomimura, Agric. Biol. Chem., 42, 909 (1978).

17) Y. Takasaki, Agric. Biol. Chem., 30, 1247 (1966).

18). Y. Takasaki, Y. Kosugi and A. Kanbayashi, Agric. Biol. Chem., 33, 1527 (1969).

19) R. Hogue-Angeletti, J. Biol. Chem., 19, 784 (1975). 